\title{
Effecten van culturele en economische hulpbronnen op toekomstverwachtingen van adolescenten
}

\author{
Author(s) \\ Keijer, Micha G.; Nagel, Ineke; Liefbroer, Aart C. \\ DOI \\ doi:10.5117/SOC2012.4.KEIJ \\ Publication date \\ 2012 \\ Document Version \\ Final published version

\section{Published in} \\ Sociologie
}

Link to publication

\section{Citation for published version (APA):}

Keijer, M. G., Nagel, I., \& Liefbroer, A. C. (2012). Effecten van culturele en economische hulpbronnen op toekomstverwachtingen van

adolescenten. Sociologie, 8(4), 382-406.

https://doi.org/doi:10.5117/SOC2012.4.KEIJ

It is not permitted to download or to forward/distribute the text or part of it without the consent of the author(s) and/or copyright holder(s), other than for strictly personal, individual use, unless the work is under an open content license (like Creative Commons).

If you believe that digital publication of certain material infringes any of your rights or (privacy) interests,

please let the Library know, stating your reasons. In case of a legitimate complaint, the Library will make the material inaccessible and/or remove it from the website. Please contact the library:

https://www.amsterdamuas.com/library/contact/questions, or send a letter to: University Library (Library of the University of Amsterdam and Amsterdam University of Applied Sciences), Secretariat, Singel 425, 1012 WP Amsterdam, The Netherlands. You will be contacted as soon as possible. 


\title{
Effecten van culturele en economische hulpbronnen op toekomstverwachtingen van adolescenten
}

\author{
Micha G. Keijer, Ineke Nagel \& Aart C. Liefbroer
}

\begin{abstract}
In de tweede helft van de twintigste eeuw is het mensbeeld sterk geïndividualiseerd. Het individu wordt gezien als de architect van zijn eigen leven en geeft aan de toekomst naar eigen inzicht betekenis. Onder sociologen is deze visie echter niet onomstreden, want velen van hen blijven het belang van de sociale, culturele en economische herkomst van individuen voor hun levensloop benadrukken. Dit artikel gaat in op deze thematiek door te bestuderen in welke mate en op welke manier de sociaaleconomische herkomst van adolescenten hun verwachtingen over toekomstige levensloopkeuzes, zowel op het vlak van werk en opleiding als op het terrein van relatievorming en gezin, beïnvloedt. Om die vraag te beantwoorden worden gegevens gebruikt uit een survey waaraan zowel 14- tot 17-jarige adolescenten als hun ouders hebben meegewerkt.
\end{abstract}

\section{Inleiding}

Levensloop is een centraal begrip in de demografie en sociologie. Uit huis gaan, van school gaan, trouwen en kinderen krijgen zijn voorbeelden van transities binnen de levensloop. Levenslooptransities, en de timing ervan, zijn niet statisch en zijn de afgelopen vijftig jaar in Nederland sterk veranderd (Liefbroer en Dykstra 2000). Het normatieve standaardpatroon van levensloopgebeurtenissen is steeds zwakker geworden (Brückner en Mayer 2005) en het aantal verschillende levensloopmogelijkheden is de laatste decennia sterk toegenomen. De vaste volgorde van studeren, een baan vinden, trouwen en kinderen krijgen wordt vaker doorbroken en nieuwe vormen van samenleven in relatie en gezin doen zich steeds vaker voor. $\mathrm{Na}$ het wegvallen van de standaardlevensloop is er een 'keuzebiografie' ontstaan (Blossfeld 2005). Binnen opleidings- en beroepsloopbanen worden capaciteiten, preferenties en mogelijkheden als steeds meer bepalend gezien voor de invulling van iemands levensloop (Giddens 1991). Deze veranderingen duiden op een individualisering van de levensloop: mensen bepalen steeds meer zelf hoe ze hun levensloop inrichten.

De adolescentie is de levensfase waarin veel van de voorkeuren, aspiraties en verwachtingen die richtinggevend zijn voor de verdere levensloop worden gevormd. Wat betreft keuzes in de opleidings- en beroepscarrière ligt dit voor de hand, omdat in het voortgezet onderwijs beslissingen worden genomen over het niveau en de richting van de (eventuele) vervolgopleiding die daarmee de beroepsloopbaan voor een belangrijk deel vastleggen. Ook wat betreft toekomstige relatie- en gezinsvorming lijkt dit het geval te zijn. Verwachtingen van adolescenten blijken 
een goede indicator te zijn voor de feitelijke levenslooptransities later in hun leven (Rimkuteet al. 2011). Volgens sommige levenslooponderzoekers wordt het plannen van de levensloop in deze levensfase steeds crucialer voor een succesvolle loopbaan (Crockett en Beal 2012). Door de verscheidenheid aan alternatieve levensstijlen is levensloopplanning noodzakelijk geworden (Giddens 1991). Anderen suggereren overigens dat jongeren geen uitgekristalliseerde levensloopverwachtingen hebben in deze fase van 'emerging adulthood' (Arnett 2000) en dat ze alle mogelijkheden openhouden.

Het is echter de vraag of de verwachtingen en aspiraties van adolescenten wel zo individueel bepaald zijn en uitsluitend tot stand komen vanuit de eigen preferenties en capaciteiten. Auteurs als Giddens (1991) en Beck en Beck-Gernsheim (2002) benadrukken weliswaar dat het individu de architect is van zijn eigen leven en alleen nog maar hoeft 'uit te zoeken' wat hij wil. Echter, empirisch onderzoek binnen de stratificatiesociologie en het levenslooponderzoek beklemtonen dat veel levensloopkeuzes nog steeds niet 'volledig vrij' zijn, maar sterk afhankelijk zijn van sociale herkomst (Van de Werfhorst, De Graaf en Kraaykamp 2001). Ondanks de individualisering in de westerse samenlevingen blijkt dat sociale klasse nog steeds een (sterke) relatie heeft met opleiding, beroep, 'lifestyle' en criminaliteit (Furlong en Cartmel 1997). Deze auteurs ontkennen niet dat capaciteiten en preferenties de levensloop van individuen voor een belangrijk deel bepalen, maar zij benadrukken dat deze ook bepaald worden door de sociale, culturele en economische achtergrond van het ouderlijk gezin (Jacob en Wilder 2010). Dit geldt niet alleen voor beslissingen in de opleidings- en beroepsloopbaan, maar ook voor die op het gebied van relatie- en gezinsvorming (De Jong-Gierveld, Liefbroer en Beekink 1991; Mayeret al. 2012).

Een aantal empirische studies laat bovendien zien dat de mate waarin adolescenten actief met hun toekomst bezig zijn, grotendeels bepaald wordt door de mogelijkheden die zij hebben. Zo laten Brannen en Nilsen (2002) in een kwalitatieve studie zien dat de ideeën over toekomstige levenslooptransities sterk samenhangen met iemands sociaaleconomische herkomst. Adolescenten met een hoge sociaaleconomische herkomst zien de toekomst als een uitdaging en zijn actief met toekomstplanning bezig, terwijl adolescenten met een lage sociaaleconomische herkomst zich niet met hun toekomst bezighouden. Ook Furlong en Cartmel (1997) benadrukken dat sociale structuren zoals klasse, ras en geslacht nog steeds een grote invloed hebben op kansen in het leven. Het gezin, de school, de vriendengroep en de cultureel-maatschappelijke consensus (Boehnke, Hadjar en Baier 2007) blijken van invloed op de verwachtingen en de planning.

De vraag doet zich dan ook voor of in de veelheid van keuzemogelijkheden adolescenten zich in hun verwachtingen en aspiraties uitsluitend laten leiden door hun eigen preferenties en capaciteiten, of dat de sociale achtergrond van het ouderlijk huis nog steeds medebepalend is.

In het licht van het 'agency'- en 'structure'-debat (Shilling 1992), benadrukt dit artikel de relatie tussen aspiraties en verwachtingen van adolescenten enerzijds (agency) en ouderlijke verwachtingen, hulpbronnen en opleidingsstructuren anderzijds (structure). De relevantie van dit onderzoek ligt vooral in het bestuderen van de verwachtingen van adolescenten. Zoals al eerder gezegd, zijn verwach- 


\section{Theoretische achtergrond}

\section{Sociaaleconomische herkomst}

De mate waarin de toekomstkansen van individuen worden beïnvloed door hun sociaaleconomische herkomst is een centraal thema in de sociologie. Het basismodel voor statusverwerving is ontwikkeld door Blau en Duncan (1967) en is veelvuldig getoetst, niet alleen cross-sectioneel maar ook in historisch en landenvergelijkend perspectief. Het Wisconsin-model (Sewell 1969) benadrukt de rol van aspiraties van adolescenten bij het tot stand komen van 'statusverwerving'. De aspiraties zouden tot stand komen door de verwachtingen van ouders en significante anderen (bijv. leraren). Een veel beperkter aantal studies heeft betrekking op de invloed van sociaaleconomische herkomst op de verwachte opleidingsen beroepsloopbaan van adolescenten. $\mathrm{Al}$ in de jaren zestig van de vorige eeuw onderzochten Duncan en Hodge (1963) de relatie tussen de beroepsstatus van de vader en de onderwijsprestaties van adolescenten. Leerlingen uit gezinnen met een hogere sociale status presteren gemiddeld beter op school en halen betere resultaten dan adolescenten uit een gezin met een lage sociale status. Hun conclusie was dat de sociaaleconomische herkomst een significante factor is bij intergenerationele overdracht van beroepskeuze. Deze conclusie houdt ook in recenter onderzoek stand (Goyette 2008). Meerdere empirische studies (Tieben, De Graaf en De Graaf 2010; De Graaf en Ganzeboom 1993; Breen en Goldthorpe 1997) bevestigen dat de onderwijsloopbaan afhankelijk is van de sociaaleconomische status (SES) van de ouders. In een internationaal comparatief onderzoek laat Noonan (1976) zien dat verschillende indicatoren voor sociaaleconomische herkomst, zoals het opleidingsniveau van de vader en de moeder, een sterke correlatie hebben met de schoolprestaties van hun kind.

Onderzoek naar intergenerationele mobiliteit en 'statusverwerving' wijst uit dat de sociale economische achtergrond van een persoon ook van groot belang is bij levenslooptransities (Conger, Conger en Martin 2010; Liefbroer en Dykstra 2000). Zo blijkt bijvoorbeeld dat de beslissing om uit huis te gaan afhankelijk is van hulpbronnen van het ouderlijk huis (Mayer et al. 2012). Vrouwen die uit huis gaan om reden van vrijheid en onafhankelijkheid, blijken dit eerder te doen naarmate hun ouders kapitaalkrachtiger zijn (De Jong-Gierveldet al. 1991).

De invloed van sociaaleconomische herkomst op levensloopverwachtingen wordt in de literatuur veelal in verband gebracht met verschillen in beschikbaarheid van en toegang tot hulpbronnen. In dit artikel wordt een onderscheid gemaakt tussen een economische en een culturele dimensie van sociale achtergrond (Bourdieu 1986). De economische status geeft met name de financiële positie van het gezin weer, terwijl de culturele status vooral het opleidingsniveau van de ouders weerspiegelt. De beide dimensies van sociale achtergrond geven de relatieve betekenis van de economische en culturele hulpbronnen van het gezin weer. Hierbij gaat het niet uitsluitend om de hoeveelheid besteedbaar inkomen en verworven diploma's, maar ook om de daaruit voortvloeiende waarden, het belang van geld, inkomenszekerheid, levensstandaard, (culturele) kennis en meer liberale of conservatieve attitudes. Hoewel de beide dimensies positief gecorreleerd zijn, geeft het onderscheid aan dat ouders met een sterke financiële positie niet per se een 
hoge opleiding hebben genoten, en omgekeerd, dat hoogopgeleide ouders niet altijd een hoog inkomen hebben. Hoewel empirisch onderzoek uitwijst dat zowel de culturele status (Zimdars, Sullivan en Heath 2009; Bourdieu 1986; Bowden en Doughney 2011; Tieben , De Graaf en De Graaf 2010; De Graaf 1986) als de economische status van het ouderlijk gezin invloed heeft op de onderwijsloopbaan van adolescenten (Nam en Huang 2009) en op de toekomstige beroepskeuzes (Goyette 2008), kunnen de culturele en economische positie ook uiteenlopende gevolgen hebben voor de toekomstverwachtingen van de kinderen. Financiële hulpbronnen - zoals het inkomen en het bezit van de ouders - zouden de socialisatie van de adolescent kunnen faciliteren (Jacob en Wilder 2010). Men kan denken aan schoolmateriaal, maar ook aan een vaste ruimte thuis waar de adolescent zijn huiswerk kan maken (Coleman 1988). Ook bijscholingscursussen en beroepskeuzetesten kunnen worden gefaciliteerd door het inkomen van de ouders. De financiële hulpbronnen worden vaak direct ingezet bij aangelegenheden omtrent de scholing van de adolescent, omdat dit in deze levensfase een van zijn of haar belangrijkste bezigheden is. Aangezien het opleidingsniveau van de adolescent in zekere mate zijn of haar toekomstperspectief structureert, zijn de financiële hulpbronnen van het ouderlijk huis daardoor mogelijk verklarend voor de toekomstverwachtingen van de adolescent (Nam en Huang 2009).

Naast de directe aanwending van de financiële hulpbronnen hebben het inkomen en kapitaal van het ouderlijk huis ook een meer latent effect op de verwachtingen van de adolescent. Ouders willen vaak dat hun kinderen het even goed of beter zullen doen dan zijzelf (Breen en Goldthorpe 1997), wat bepaalde verwachtingen ten aanzien van de adolescent met zich meebrengt. Daarnaast zijn de adolescenten gewend geraakt aan een bepaald bestedingspatroon, dat vaak gefinancierd wordt door de ouders. Ze zijn een bepaalde levensstandaard normaal gaan vinden en verwachten, indien mogelijk, deze levensstandaard voort te zetten (Easterlin 1995).

Naast financiële hulpbronnen kunnen ook culturele hulpbronnen de toekomstverwachtingen van adolescenten structureren (Zimdars, Sullivan en Heath 2009). Culturele hulpbronnen verwijzen niet alleen naar het opleidingsniveau van de ouders, maar ook naar de immateriële dimensie in de vorm van vaardigheden en waarden die een hoog opleidingsniveau met zich meebrengt, zoals de bekendheid met hoge cultuur (Bourdieu 1986) en verschillende stijlen van opvoeding (Kohn 1963). De economische en culturele status van de ouders beïnvloeden mogelijk ook verwachtingen over relatievorming en gezin (Conger, Conger en Martin 2010). Zo kan een adolescent afkomstig uit een ouderlijk huis met veel culturele hulpbronnen 'vrijere en vooruitstrevendere' ideeën hebben omtrent relatievorming en gezin dan een adolescent met een lagere sociaaleconomische herkomst (Liefbroer en Billari 2010). Daarnaast kan men zich voorstellen dat een adolescent die afkomstig is uit een gezin met minder economische en culturele hulpbronnen, een traditionelere houding heeft 'meegekregen'.

Michael en Tuma (1985) en De Jong-Gierveld et al. (1991) suggereren dat verwachtingen omtrent levenslooptransities in de privésfeer ook beïnvloed kunnen worden door de financiën van het ouderlijk huis. Michael en Tuma (1985) vonden in de VS positieve correlaties tussen het inkomen van de ouders en de leeftijd 
waarop men trouwt en kinderen krijgt. Hun studie komt overeen met het theoretische idee van Becker (1974) dat een minder goede thuissituatie, zowel financieel als emotioneel, leidt tot het eerder verlaten van het ouderlijk huis.

\section{Keuzes en verwachtingen}

De hiervoor beschreven literatuur bestudeert veelal feitelijke keuzes en beslissingen, maar ziet deze keuzes als de uitkomst van een complex keuzeproces waarin verwachtingen en plannen van jongeren worden afgestemd op de feitelijke en gepercipieerde mogelijkheden (Nurmi 1991). Dit roept de vraag op op welke manier deze verwachtingen aangaande levensloopkeuzes worden beïnvloed door het ouderlijk huis. De eerder besproken literatuur suggereert dat de sociaaleconomische herkomst deze verwachtingen deels beïnvloedt via het onderwijssysteem, maar dat ouders ook meer direct de verwachtingen van hun kinderen beïnvloeden, en wel via een proces van intergenerationele overdracht van waarden en attitudes.

Er is veel onderzoek gedaan naar de intergenerationele overdracht van waarden en attitudes in gezinnen (Roest 2009; Axinn en Thornton 1993), waaruit blijkt dat er een behoorlijk sterke correlatie bestaat tussen de waarden van ouders en kinderen. Binnen het gezin beïnvloeden de ouders hun kinderen sterker dan de kinderen hun ouders, maar de relatie is dus niet volledig 'eenrichtingsverkeer' (Roest 2009). Welke waarden en attitudes ouders en kinderen hebben, wordt voor een groot deel verklaard door de sociaaleconomische positie van het gezin (Conger, Conger en Martin 2010; Axinn en Thornton 1992).

\section{Schoolniveau en socialisatie in relatie tot levensloopverwachtingen}

De tweede vraag in dit onderzoek is via welke mechanismen de ouderlijke hulpbronnen de verwachtingen en ambities van adolescenten beïnvloeden. Het vermoeden is dat toekomstplannen, met name die op het vlak van opleiding en werk, sterk gestructureerd worden door het schoolniveau, omdat dit immers in sterke mate de capaciteiten van de adolescent zelf weerspiegelt. Kinderen van wie de ouders een hoge sociaaleconomische positie hebben, hebben een grotere kans een hoog opleidingsniveau te bereiken dan kinderen van wie de ouders een lage sociaaleconomische status hebben (Bowden en Doughney 2011; Tieben, De Graaf en De Graaf 2010). Het verband tussen met name het opleidingsniveau van de ouders en het schoolsucces van de kinderen kan worden verklaard door de culturele reproductietheorie. De dominantie van de culturele middenklasse op het gebied van opvoeding en scholing zou een achterstand creëren voor kinderen met een lagere sociale achtergrond (Bourdieu en Passeron 1977). Hoogopgeleide ouders zouden hun kinderen beter kunnen helpen bij het maken van huiswerk, en ze ook bekendmaken met bepaalde vormen van cultuur, zoals musea, boeken en digitale media, die in het onderwijs gewaardeerd worden. Daarnaast zouden de verwachtingen van leraren ongelijkheid in de hand werken (Harvey en Slatin 1975). Leraren hebben hogere verwachtingen over kinderen uit de middenklasse: 'the middle class bias'. Kinderen uit hogere sociale milieus hebben daardoor op school een voorsprong op kinderen uit lagere sociale milieus. Empirisch onderzoek laat zien dat het cultureel kapitaal van de ouders een positief effect heeft op 
de onderwijskansen van hun kinderen (Kraaykamp 2009; Bourdieu en Passeron 1977; Aschaffenburg en Maas 1997; De Graaf et al. 2000; Van Wel et al. 2006; Notten en Kraaykamp 2010; Kraaykamp en Van Eijck 2010). Kortom, de sociale achtergrond van de ouders zal de toekomstplannen van de kinderen deels beïnvloeden doordat kinderen van ouders met een hogere sociaaleconomische positie een hoger schoolniveau in het voortgezet onderwijs bereiken.

Het bereikte opleidingsniveau van de adolescent structureert vervolgens ook weer zijn of haar verwachtingen. Allereerst beïnvloedt het huidige opleidingsniveau de mogelijkheid tot doorstuderen en de duur daarvan. Daarnaast beïnvloedt het huidige opleidingsniveau de toegang tot verschillende delen van de arbeidsmarkt. Ook stellen hoger opgeleiden relaties en gezinsvorming vaak uit, omdat dit vaak moeilijk te combineren valt met het volgen van een studie en de start van een carrière (Clarkberg en Moen 2001; Blossfeld en Huinink 1991). Bovendien zijn hoger opgeleiden vaak meer gesteld op hun vrijheid en hebben daarom andere normen en verwachtingen aangaande gezinsvorming (Liefbroer en Billari 2010).

Naast de structurerende rol van het huidige opleidingsniveau benadrukken ontwikkelingsstudies daarentegen de socialiserende rol van ouders. De ouders slagen er veelal in, ook buiten het onderwijssysteem om, hun opvattingen aan hun kinderen over te dragen (Kim en Schneider 2006; Davies en Kandel 1981). Nog weinig empirisch onderzoek is gedaan naar de effecten van de verwachtingen van de ouders op de aspiraties en verwachtingen van adolescenten. Het al eerdergenoemde Wisconsin-model (Sewell, Haller en Portes 1969) benadrukt de rol van aspiraties van adolescenten bij het tot stand komen van 'statusverwerving'. Empirische studies laten zien dat ook deze conclusies de tand des tijds doorstaan (Bowden en Doughney 2011).

Ook is nog weinig bekend over de mate waarin de verwachtingen van de ouders gestructureerd worden door hun sociale achtergrond en dus in hoeverre eventuele verschillen in toekomstplannen bij adolescenten het gevolg zijn van directe socialisatie. In dit artikel gaan we na in hoeverre de verwachtingen en aspiraties van de ouders de toekomstplannen van hun kind beïnvloeden, rekening houdend met het reeds bereikte niveau van voortgezet onderwijs.

\section{Verschillen tussen verwachtingen over opleiding en beroep en over relatie- en gezinsvorming}

De laatste vraag in dit onderzoek heeft betrekking op het verschil tussen de twee domeinen. Beïnvloedt de sociaaleconomische herkomst de verwachtingen in het domein van opleiding en beroep anders dan de verwachtingen in het domein van relatievorming en gezin? De literatuur geeft geen eenduidig antwoord op de vraag of het effect van de sociaaleconomische herkomst per domein verschilt. Aan de ene kant kunnen sterkere effecten verwacht worden van de sociale achtergrond van de ouders op het domein van opleiding en beroep dan op het domein van relatie- en gezinsvorming. Immers, de sociale achtergrond van de ouders - hier gemeten als inkomen en opleiding - heeft betrekking op hetzelfde domein van opleiding en beroep. Bovendien streven ouders naar ten minste dezelfde of een hogere sociaaleconomische status voor hun kinderen (Breen en Goldthorpe 1997), wat suggereert dat ouders een sterke invloed hebben op de opleiding en het beroep 
Figuur 1 Conceptueel model van de relatie tussen de sociaaleconomische herkomst van adolescenten en hun toekomstverwachtingen

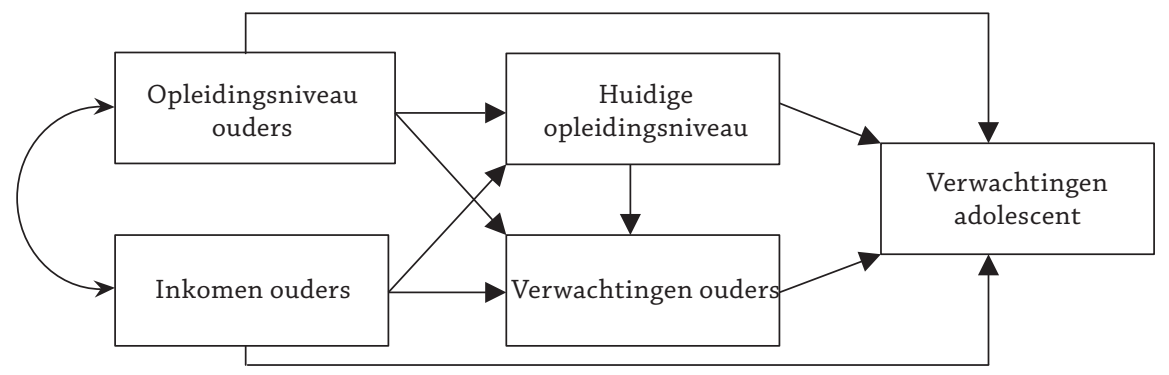

van hun kind. Omdat de leefsituatie van hedendaagse adolescenten sterk verschilt van die van hun ouders, wordt het bovendien moeilijker om hun opvattingen omtrent relaties en gezin aan hun kinderen over te brengen. Daarnaast zijn ouders heden ten dage minder geneigd om zich te mengen in het gezinsdomein van hun kinderen (Kalmijn 1998), waardoor hun invloed waarschijnlijk sterker zal zijn op het domein van opleiding en beroep.

Aan de andere kant zijn juist keuzes op het gebied van opleiding en beroep sterk afhankelijk van de eigen capaciteiten van de adolescent, waarop in het onderwijs sterk geselecteerd wordt, terwijl keuzes op het gebied van relatie- en gezinsvorming in het onderwijs juist minder aan de orde komen. Bovendien wordt in een steeds sneller veranderende arbeidsmarkt socialisering omtrent beroepen door het ouderlijk huis waarschijnlijk moeilijker. Daarnaast suggereren Aldous en Hill (1965) dat ouders juist vooral zullen proberen hun kinderen te beïnvloeden rond keuzes die betrekking hebben op het voortzetten van de gezinslijn. Op basis hiervan zou juist een grotere invloed van de ouders op het domein van relatie- en gezinsvorming verwacht kunnen worden dan op het domein van opleiding en beroep.

Omdat er zowel theoretische argumenten zijn om te veronderstellen dat ouders vooral de plannen van hun kinderen omtrent werk en carrière zullen beïnvloeden, als argumenten om te veronderstellen dat ze juist plannen omtrent gezinsvorming zullen beïnvloeden, en vanwege het ontbreken van empirische informatie daaromtrent, zien wij op dit punt af van het formuleren van expliciete hypotheses.

\section{Overzicht}

Figuur 1 is een grafische weergave van de hiervoor beschreven relaties. De invloed van de culturele en economische hulpbronnen van de ouders op de verwachtingen van de adolescent worden in dit model gemedieerd door het schoolniveau en de verwachtingen van de ouders. Het schoolniveau van de adolescent reflecteert de eigen capaciteiten en deels waarschijnlijk ook de reeds verzilverde ouderlijk hulpbronnen. De verwachtingen van de ouders in relatie tot verwachtingen van de adolescent geven de mate van gezinssocialisatie weer. 


\section{Data en meetinstrumenten}

\section{De data}

De gebruikte data zijn verzameld in 2005 (Ganzeboom, Nagel en Liefbroer 2005-2006) en maken deel uit van het grotere onderzoeksproject Jeugd en Cultuur (Ganzeboom en Nagel, 1998-2002), dat meerdere studies naar leerlingen in het voortgezet onderwijs in Nederland omvat. De dataverzameling vond plaats tussen september en november 2005 in veertien gemeentes in Nederland. De keuze van de gemeentes is gebaseerd op het design van eerdere dataverzamelingen binnen het Jeugd en Cultuur-project. De gemeentes verschillen in grootte en liggen verspreid over heel Nederland. Er waren twee grote steden (Rotterdam, Utrecht), acht middelgrote gemeentes (Alkmaar, Amersfoort, Delft, Enschede, Gouda, Haarlem, Nijmegen, Zwolle) en vier kleine gemeenten (Emmeloord, Goes, Steenwijk, Weert) geselecteerd. Binnen deze gemeentes was contact gezocht met 69 scholen, waarvan 60 scholen bereid waren te participeren in het onderzoek. Alle mogelijke scholingsniveaus in het Nederlands voortgezet onderwijs (vmbo-b, mavo/vmbo-t, havo en vwo (inclusief gymnasium)) zijn vertegenwoordigd in de steekproef (Nagel 2007).

Binnen iedere geselecteerde school is een gestratificeerde steekproef getrokken. De stratificatie heeft plaatsgevonden naar vier verschillende scholingsniveaus (vmbo-b, mavo/vmbo-t, havo en vwo) en het leerjaar ( 3,4 of 5 ) van de desbetreffende klas. Binnen de school werd er een steekproef getrokken van drie klassen (bijv. havo 3c, vwo 5a en vmbo-t 4b). ${ }^{1}$ De steekproef moest aan de voorwaarde voldoen dat er geen overlap zou zijn tussen klassen met betrekking tot het scholingsniveau en het leerjaar binnen een school. Deze procedure resulteerde in 190 klassen, waarvan er uiteindelijk 148 werkelijk meededen aan het project. De respons is $87 \%$ op het niveau van de scholen en $78 \%$ op het niveau van de klassen. In iedere klas is de leerlingen gevraagd een enquête in te vullen tijdens een lesuur (45-50 minuten). Omdat de dataverzameling deel uitmaakt van een groter project, zijn de klassen aselect in tweeën verdeeld; één helft van de klas kreeg een enquête omtrent toekomstplannen en cultuurdeelname voorgelegd, de andere helft kreeg een enquête over computergebruik. Uiteindelijk participeerden 1544 leerlingen in het onderzoek naar toekomstplannen. De exacte respons op het niveau van de leerlingen is niet te bepalen, omdat het exacte aantal leerlingen in een klas niet van tevoren bekend was. Er mag verondersteld worden dat de selectieve non-respons vrij klein is, vanwege het klassikale karakter van de enquête.

In januari 2006 hebben de ouders eveneens een enquête over de toekomstplannen van hun kind via de post ontvangen. Bij tweeoudergezinnen is een willekeurig gekozen ouder benaderd; bij eenoudergezinnen is de ouder gevraagd bij wie de desbetreffende leerling woont. Uiteindelijk leidde dit tot 981 adolescent-ouderparen in het onderzoek. Dit is een respons van de ouders van $64 \%$. De non-res- 
pons van de ouders blijkt niet selectief te zijn wat betreft inkomen en opleidingsniveau van het ouderlijk huis. Het item non-respons binnen de enquêtes, zowel bij de ouders als bij de adolescenten, blijkt bij nadere analyse ook geen selectiviteit te vertonen qua opleidingsniveau en inkomen van het ouderlijk huis.

\section{Meetinstrumenten}

\section{Toekomstverwachtingen van adolescenten en ouders: opleiding}

Op de vraag: Welk opleidingsniveau denk je uiteindelijk te bereiken?, konden de adolescenten voor elk van de zes voorgelegde opleidingsniveaus (vmbo, mbo, havo, vwo, hbo en universiteit) aangeven of zij dit niveau zeker niet, waarschijnlijk niet, waarschijnlijk wel of zeker wel dachten te bereiken. Hierna is op basis van de antwoorden op deze zes vragen een schaal gecreëerd, waarbij ieder scholingsniveau een ISLED-codering (Schröder en Ganzeboom 2011) heeft gekregen. De antwoorden waarschijnlijk wel en zeker wel bij de hoogst haalbare opleiding zijn de voorwaarde voor het toekennen van bijbehorende ISLED-codering. ISLED is een, empirisch verkregen, internationaal vergelijkbare intervalschaal voor opleidingsniveaus, waarvan de waarde theoretisch kan variëren tussen 0 en 100 . In dit onderzoek varieert het opleidingsniveau van 25,7 (lagere school) tot 84,7 (universitair) (zie tabel 1). Bij de ouders zijn de aspiraties gemeten met de volgende vraag: Welk opleidingsniveau zou u willen dat uw zoon of dochter uiteindelijk bereikt? De antwoordcategorieën zijn absoluut niet, liever niet, misschien en graag. Vervolgens is op dezelfde wijze een schaal gecreëerd (zie tabel 2). Het is opvallend dat de wensen van de ouders omtrent het uiteindelijke opleidingsniveau van hun kind een stuk hoger uitvallen dan de verwachtingen van de adolescenten zelf (zie tabel 2). Van de adolescenten verwacht $36,5 \%$ waarschijnlijk tot zeker een hbodiploma te behalen. Een vergelijkbaar percentage $(38,8 \%)$ verwacht een universitaire graad te behalen. Dit staat in schril contrast met de voorkeuren van de ouders: $22,1 \%$ prefereert dat het hbo en $65,6 \%$ dat een universitaire graad misschien of graag behaald wordt. Mogelijk valt het verschil tussen ouders en kinderen te verklaren door de vraagstelling; het verschil tussen verwachtingen (wat denkje) en wensen (wat wil je).

\section{Toekomstverwachtingen van adolescenten en ouders: beroep}

Over de verwachte beroepsstatus is de volgende vraag gesteld: Hoe graag zou je de volgende beroepen willen uitoefenen? De leerling kreeg een beroepenlijst voorgelegd van 30 verschillende beroepen. Om de voorkeur voor de verschillende beroepen uit te drukken kon geantwoord worden op de volgende schaal: absoluut niet, liever niet, misschien en graag. Aan de beroepen, variërend van arts tot kapper, zijn twee statusscores toegekend, op basis van de door Ganzeboom, De Graaf en Kalmijn (1987) ontwikkelde schaal om de culturele en economische status van het beroep weer te geven. De culturele en economische beroepsstatus van de verschillende beroepen zijn sterk gecorreleerd, maar geven toch een nuancering van de beroepsvoorkeur. Het meetinstrument is als volgt geconstrueerd: de economische en culturele beroepsstatus is vermenigvuldigd met de desbetreffende beroepsvoorkeur 
Tabel 1 Beschrijvende statistieken

\begin{tabular}{|c|c|c|c|c|c|}
\hline & Minimum & Maximum & $\begin{array}{l}\text { Gemid- } \\
\text { delde }\end{array}$ & $\begin{array}{l}\text { Std. } \\
\text { deviatie }\end{array}$ & $\mathbf{N}$ \\
\hline $\begin{array}{l}\text { Opleidingsniveau adolescent } \\
\text { (ISLED) }\end{array}$ & 31.90 & 69.80 & 58.88 & 12.76 & 968 \\
\hline $\begin{array}{l}\text { Opleidingsniveau ouders (gemid- } \\
\text { deld ISLED) }\end{array}$ & 19.10 & 84.70 & 62.33 & 15.83 & 968 \\
\hline Inkomen ouders (equivalentiecijfer) & 424.76 & 5339.81 & 1687.10 & 749.42 & 809 \\
\hline $\begin{array}{l}\text { Verwacht uiteindelijk educatie- } \\
\text { niveau }\end{array}$ & 25.70 & 84.70 & 74.41 & 11.53 & 952 \\
\hline $\begin{array}{l}\text { Verwacht uiteindelijk educatie- } \\
\text { niveau (ouders) }\end{array}$ & 25.70 & 84.70 & 79.15 & 9.61 & 969 \\
\hline $\begin{array}{l}\text { 'Culturele status' beroepspreferen- } \\
\text { tie }\end{array}$ & -.18 & 1.28 & .44 & .23 & 901 \\
\hline $\begin{array}{l}\text { 'Culturele status' beroepspreferen- } \\
\text { tie (ouders) }\end{array}$ & -.15 & 1.53 & .49 & .28 & 901 \\
\hline $\begin{array}{l}\text { 'Economische status' beroepsprefe- } \\
\text { rentie }\end{array}$ & -.86 & 1.37 & .54 & .31 & 950 \\
\hline $\begin{array}{l}\text { 'Economische status' beroepsprefe- } \\
\text { rentie (ouders) }\end{array}$ & -.90 & 1.61 & .60 & .36 & 950 \\
\hline Verwachte leeftijd trouwen & 15.00 & 40.00 & 26.11 & 3.28 & 661 \\
\hline Verwachte leeftijd kinderen & 13.00 & 40.00 & 27.34 & 3.55 & 674 \\
\hline Verwachte leeftijd samenwonen & 16.00 & 35.00 & 23.97 & 3.04 & 669 \\
\hline Verwachte leeftijd huis kopen & 16.00 & 40.00 & 25.82 & 3.96 & 696 \\
\hline $\begin{array}{l}\text { Verwachte leeftijd trouwen } \\
\text { (ouders) }\end{array}$ & 16.00 & 40.00 & 27.56 & 2.94 & 626 \\
\hline $\begin{array}{l}\text { Verwachte leeftijd kinderen } \\
\text { (ouders) }\end{array}$ & 16.00 & 39.p00 & 29.05 & 2.73 & 747 \\
\hline $\begin{array}{l}\text { Verwachte leeftijd samenwonen } \\
\text { (ouders) }\end{array}$ & 16.00 & 35.00 & 24.70 & 2.65 & 684 \\
\hline $\begin{array}{l}\text { Verwachte leeftijd huis kopen } \\
\text { (ouders) }\end{array}$ & 16.00 & 40.00 & 27.80 & 3.12 & 706 \\
\hline Belangrijk voor je 30 ste getrouwd & 1.00 & 5.00 & 3.42 & 1.06 & 889 \\
\hline Belangrijk voor je 30 ste kind & 1.00 & 5.00 & 3.44 & 1.06 & 889 \\
\hline $\begin{array}{l}\text { Belangrijk voor je 30ste getrouwd } \\
\text { (ouders) }\end{array}$ & 1.00 & 5.00 & 2.75 & .90 & 928 \\
\hline $\begin{array}{l}\text { Belangrijk voor je } 30 \text { ste getrouwd } \\
\text { (kind) }\end{array}$ & 1.00 & 5.00 & 2.76 & .84 & 925 \\
\hline
\end{tabular}

(absoluut niet $=1$, liever niet $=2$, misschien $=3$ en graag $=4$ ). Vervolgens is er een gemiddelde berekend van de 30 op deze wijze verkregen scores. Dit resulteert in twee algemene beroepsvoorkeurindices, één voor economische en één voor culturele beroepen (zie tabel 2). Hoe hoger de score op de culturele beroepsvoorkeurindex, des te sterker de voorkeur voor culturele beroepen. Ook aan de ouders is gevraagd: Hoe graag zou u willen dat uw zoon of dochter de volgende beroepen zou 


\begin{tabular}{|c|c|c|c|c|}
\hline & & $\begin{array}{l}\text { Adolescen- } \\
\text { ten }\end{array}$ & Ouders & $n$ \\
\hline \multirow{3}{*}{$\begin{array}{l}\text { Welk opleidingsniveau denk je uiteinde- } \\
\text { lijk te bereiken? (adolescenten: \% waar- } \\
\text { schijnlijk tot zeker wel; ouders: \% mis- } \\
\text { schien of graag) }\end{array}$} & MBO & 10,1 & 6,3 & 940 \\
\hline & $\mathrm{HBO}$ & 36,5 & 22,1 & 940 \\
\hline & Universiteit & 38,8 & 65,6 & 940 \\
\hline $\begin{array}{l}\text { Welk beroep wil je absoluut niet uitoefe- } \\
\text { nen? (minst populaire beroep onder ado- } \\
\text { lescenten in \%) }\end{array}$ & Schoonmaker & 78,9 & 56,2 & 763 \\
\hline $\begin{array}{l}\text { Welk beroep wil je graag uitoefenen? } \\
\text { (populairste beroep onder adolescenten } \\
\text { in \%) }\end{array}$ & $\begin{array}{l}\text { Directeur middel- } \\
\text { groot bedrijf }\end{array}$ & 16,7 & 14,3 & 784 \\
\hline \multirow[t]{2}{*}{ Verwacht je dit mee te maken? (\% ja) } & te trouwen & 90,8 & 84,3 & 682 \\
\hline & kinderen te krijgen & 90,2 & 92,8 & 682 \\
\hline \multirow{2}{*}{$\begin{array}{l}\text { Hoe belangrijk is het voor jou om op je } \\
\text { dertigste... (\% belangrijk tot zeer belang- } \\
\text { rijk) }\end{array}$} & getrouwd te zijn & 47,6 & 16,6 & 682 \\
\hline & kinderen te hebben & 50,0 & 13,6 & 682 \\
\hline Eerst trouwen, daarna kinderen $(\%$ ja $)$ & & 64,6 & 61,6 & 395 \\
\hline
\end{tabular}

gaan uitoefenen? Hierbij zijn op dezelfde wijze als bij de adolescenten twee indices voor beroepsvoorkeur gecreëerd (zie tabel 1). Uit de antwoorden blijkt dat onder de adolescenten het minst populaire beroep schoonmaker is (zie tabel 2). Dit beroep heeft zowel een lage economische als een lage culturele status. Het meest populaire beroep onder de adolescenten is directeur van een middelgroot bedrijf, dit beroep heeft voornamelijk een hoge economische status. Het op één na meest populaire beroep is muzikant, een beroep met voornamelijk culturele status. Bij de ouders was arts het meest populaire beroep, een professie met zowel een hoge economische als een hoge culturele status. Verder blijkt uit de antwoorden dat er onder de adolescenten en ouders veel meer overeenstemming is over welk beroep men absoluut niet wil uitoefenen dan over welk beroep men graag wil uitoefenen.

\section{Toekomstverwachtingen van adolescenten en ouders: belang gezinsvorming}

De vragen over het domein van relatie- en gezinsvorming gaan over het belang dat men hecht aan gezinsvorming en de timing van gezinsvorming. De volgende vragen zijn gesteld: Hoe belangrijk is het voor jou om op je dertigste getrouwd te zijn? en ... een kind te hebben? Hierbij moest men op een vijfpuntsschaal van zeer onbelangrijk tot zeer belangrijk antwoord geven. Deze twee vragen zijn de indicatoren van de latente variabele 'centraliteit gezin' in het te schatten model. Tevens is er aan de ouders de vraag gesteld: Hoe belangrijk is het voor u dat uw zoon of dochter op zijn of haar dertigste getrouwd is? en ... kinderen heeft? Deze twee vragen zijn vrijwel identiek aan de gestelde vragen aan de adolescent. De antwoorden zijn daarom ook op dezelfde manier behandeld als bij de adolescent. Er is overeenstemming tussen de ouders en de adolescenten over het krijgen van kinderen: 
ongeveer $90 \%$ van de ouders en de adolescenten verwacht dit (zie tabel 2). Tevens verwacht $92,8 \%$ van de adolescenten en $84,3 \%$ van de ouders een huwelijk. Het grote verschil tussen de ouders en de adolescenten is het belang dat men hecht aan trouwen en kinderen krijgen. Bijna 50\% van de adolescenten die een huwelijk en kinderen verwachten, vindt trouwen en kinderen krijgen voor hun dertigste belangrijk tot zeer belangrijk. Hun ouders waarderen het huwelijk en het krijgen van nageslacht voor het dertigste levensjaar een stuk lager: respectievelijk $16,6 \%$ en $13,6 \%$ vindt dit belangrijk tot zeer belangrijk.

\section{Toekomstverwachtingen van adolescenten en ouders: timing gezinsvorming}

De timing van gezinsvorming is gemeten door te vragen naar de leeftijden waarop de adolescent verwacht te trouwen, een kind te krijgen, samen te gaan wonen met een partner en een eigen huis te kopen. De geantwoorde leeftijden ${ }^{2}$ vormen de indicatoren voor de latente variabele 'timing gezin' in het te schatten model. Om de verwachtingen van de ouders over de timing van gezinsvorming van hun kind te meten zijn de hiervoor gestelde vragen ook aan de ouders voorgelegd. Zo'n 63\% van de ouders en de adolescenten prefereert eerst een huwelijk en dan pas een kind. Een vijfde van de adolescenten en een derde van de ouders prefereert een huwelijk en kinderen in hetzelfde levensjaar. Dit bevestigt enigszins het traditionele stereotype van eerst een huwelijk en daarna een kind. Het algemene beeld omtrent timing van gezinsvorming is dat ouders en adolescenten de levenslooptransities in dezelfde volgorde verwachten. Echter, de ouders verwachten de verschillende levenslooptransities later dan de adolescenten ${ }^{3}$ (zie tabel 1).

\section{Overige variabelen}

De sociale achtergrond van de ouders is opgedeeld in twee dimensies die de economische en culturele hulpbronnen weerspiegelen. De culturele hulpbronnen worden gemeten in de geïnstitutionaliseerde vorm, namelijk het door de ouders bereikte opleidingsniveau. Het opleidingsniveau van beide ouders is gemeten op een schaal van één tot negen (geen opleiding=1, basisschool, lager beroepsonderwijs, mavo, middelbaar beroepsonderwijs, havo, vwo, hbo, universiteit=9). Vervolgens zijn de opleidingsniveaus uitgedrukt in ISLED-coderingen (geen opleiding=19,1 t/m universiteit=84,7) en zijn het opleidingsniveau van de vader en de moeder gemiddeld (zie tabel 1).

De economische hulpbronnen worden weergegeven door het inkomen van het ouderlijk huis. Het inkomen per ouder is gevraagd op een schaal van 1 tot 16 . Hierbij staat 1 voor 'geen inkomsten' en 16 staat voor meer dan $€ 5000$ aan netto inkomsten per maand. Van de 16 verschillende antwoordmogelijkheden is de middenklasse gebruikt. De hoogste inkomensklasse $€ 5000$ of meer heeft als middenklasse $€ 5500$ gekregen. Hierna is via sommatie het gezamenlijk inkomen van

2 Indien er een leeftijdsbereik is geantwoord, is het midden van dit bereik meegenomen in de analyse.

3 Naast de reguliere missing values en 'niet codeerbare antwoorden' zijn er ook ouders en kinderen die geen verwachte leeftijd hebben genoemd omdat ze niet verwachtten de betreffende gebeurtenis mee te maken (ongeveer 10\%). 
beide ouders berekend. Vervolgens is het gezinsinkomen gestandaardiseerd door equivalentiefactoren te gebruiken (Sierman et al. 2004). Hierdoor kunnen de inkomens van huishoudens met verschillende omvang en samenstelling beter met elkaar worden vergeleken. Omdat de enquête aan een van de ouders is voorgelegd, wordt er verondersteld dat de 'invullende ouder' voldoende inzicht heeft in de opleiding en het inkomen van zijn of haar partner (zie tabel 1).

Het huidige schoolniveau van de adolescent is het niveau dat door de adolescent is gerapporteerd. Dit kan variëren van vmbo- $b$, vmbo-t, havo, vwo/atheneum/ gymnasium. De antwoorden zijn vervolgens uitgedrukt in ISLED-coderingen variërend van 31,90 tot 69,80 (zie tabel 1 ).

\section{Methode en modellen}

Om de relaties tussen de ouderlijke hulpbronnen en de toekomstverwachtingen van adolescenten te schatten is gebruikgemaakt van structural equations modeling (SEM). SEM maakt het mogelijk om het conceptuele padmodel zoals weergegeven in figuur 1 in zijn geheel te toetsen. Naast het schatten van de directe en indirecte paden zijn ook de totale effecten van de ouderlijke hulpbronnen op de verwachtingen van de adolescent geschat. Vanwege het item non-respons in de data zijn de modellen via de 'full information maximum likelihood'-methode geschat in Mplus (Muthén en Muthén 2004), waarbij een clustercorrectie is toegepast op het niveau van de klassen. In de geschatte SEM-modellen zijn zowel manifeste als latente variabelen opgenomen. Manifeste variabelen worden weergegeven door een rechthoek, latente variabelen door een ovaal. De factorladingen van de latente variabelen, verkregen door 'confirmatory factor analyses' binnen het SEM-model, staan in tabel 3 weergegeven. In eerste instantie zijn deze modellen afzonderlijk geschat voor jongens en meisjes. De resultaten kwamen echter in zo sterke mate overeen, dat er voor is gekozen om de gegevens van jongens en meisjes gezamenlijk te analyseren en presenteren.

Er zijn vijf modellen geschat. Drie modellen gaan over verwachtingen over opleiding en beroep, met als afhankelijke variabelen het verwachte uiteindelijke opleidingsniveau, de 'economische beroepspreferentie' en de 'culturele beroepspreferentie'. Twee modellen betreffen het domein relatie- en gezinsvorming, met als afhankelijke variabelen de centraliteit van gezinsvorming en de timing van gezinsvorming. In de gerapporteerde figuren zijn de significante gestandaardiseerde coëfficiënten $(\beta$ 's) weergegeven ( $p$-waarde $<0,05$, n.s. $=$ niet significant). De verschillende fitmaten geven weer hoe goed de data aansluiten bij het beschreven conceptuele model. De modellen aangaande opleiding en beroep zijn 'just identified'. Om toch de fit-maten te bereken is een niet significant pad (opleiding ouders $\rightarrow$ verwachting ouders) voor de berekening uit het model gehaald.

\section{Resultaten}

In de eerste plaats wordt aandacht besteed aan de totale invloed van de ouderlijke hulpbronnen op de verwachtingen van de adolescent. Tabel 4 vermeldt de totale 


\begin{tabular}{lllll}
\hline & \multicolumn{2}{c}{ Centraliteit gezin } & \multicolumn{2}{c}{ Timing gezin } \\
Factorladingen & Ouders & Adolescent & Ouders & Adolescent \\
\hline Trouwen voor je 30ste? (I t/m 5) & 0,96 & 0,99 & & \\
Kinderen voor je 30ste? (I t/m 5) & 0,77 & 0,72 & & \\
Leeftijd trouwen (in jaren) & & & 0,82 & 0,80 \\
Leeftijd kinderen (in jaren) & & & 0,86 & 0,78 \\
Leeftijd samenwonen (in jaren) & & & 0,72 & 0,68 \\
Leeftijd huis kopen (in jaren) & & & 0,76 & 0,61 \\
\hline
\end{tabular}

Tabel 4

Totale effecten van ouderlijke hulpbronnen op verwachtingen adolescent

\begin{tabular}{rlllll}
\hline \multicolumn{7}{c}{ Verwachtingen kind } \\
Totale effecten & Scholingsniveau & Econ. baan & Cult. baan & Centraliteit & Timing \\
\hline Ouders educatie & $0,21^{*}$ & 0,04 & $0,14^{*}$ & $-0,09^{*}$ & $0,18^{*}$ \\
inkomen & $0,15^{*}$ & $0,16^{*}$ & $0,11^{*}$ & $-0,06$ & $0,15^{*}$ \\
\hline
\end{tabular}

effecten van het opleidingsniveau en het inkomen van de ouders op de vijf verschillende verwachtingen. Het huidige scholingsniveau van de adolescent en de verwachtingen van de ouders zijn nu nog buiten beschouwing gelaten.

De verwachting van de adolescent over het uiteindelijk te bereiken scholingsniveau hangt significant samen met het opleidingsniveau $(\beta=0,21)$ en het inkomen $(\beta=0,15)$ van de ouders. Hoe hoger het opleidingsniveau en het inkomen van de ouders, des te hoger is het opleidingsniveau dat de adolescent denkt te behalen. De verwachte economische beroepskeuze hangt alleen significant samen met het inkomen $(\beta=0,16)$ van de ouders, terwijl de culturele beroepskeuze significant samenhangt met het opleidingsniveau $(\beta=0,14)$ en het inkomen $(\beta=0,11)$ van de ouders.

Het belang dat de adolescent hecht aan gezinsvorming hangt negatief samen $(\beta=-0,09)$ met de ouderlijke culturele hulpbronnen. Adolescenten met hoger opgeleide ouders vinden trouwen en kinderen krijgen minder belangrijk dan hun leeftijdgenoten van wie de ouders lager zijn opgeleid. Het opleidingsniveau van de ouders beïnvloedt ook de verwachte timing van levensgebeurtenissen $(\beta=0,18)$ : kinderen uit hoogopgeleide gezinnen verwachten op latere leeftijd een vaste relatie aan te gaan en kinderen te krijgen en een huis te kopen dan kinderen van wie de ouders lager opgeleid zijn. Ook het inkomen van de ouders heeft een zelfstandig effect $(\beta=0,15)$ : een hoger inkomen van de ouders leidt tot latere timing van deze levensgebeurtenissen.

Om de effecten van sociaaleconomische herkomst te verklaren worden het scholingsniveau van de adolescent en de verwachtingen van de ouders als mediërende variabelen aan het model toegevoegd. In figuur 2 zijn de geschatte effecten voor het verwachte uiteindelijke scholingsniveau weergegeven. Zowel het opleidings- 
Figuur 2 Het verwachte uiteindelijke opleidingsniveau: effecten van sociale achtergrond, schoolniveau en verwachtingen van de ouders $(d f=1$, $X 2=1,02, R M S E A=0,0004, C F I=1$ )

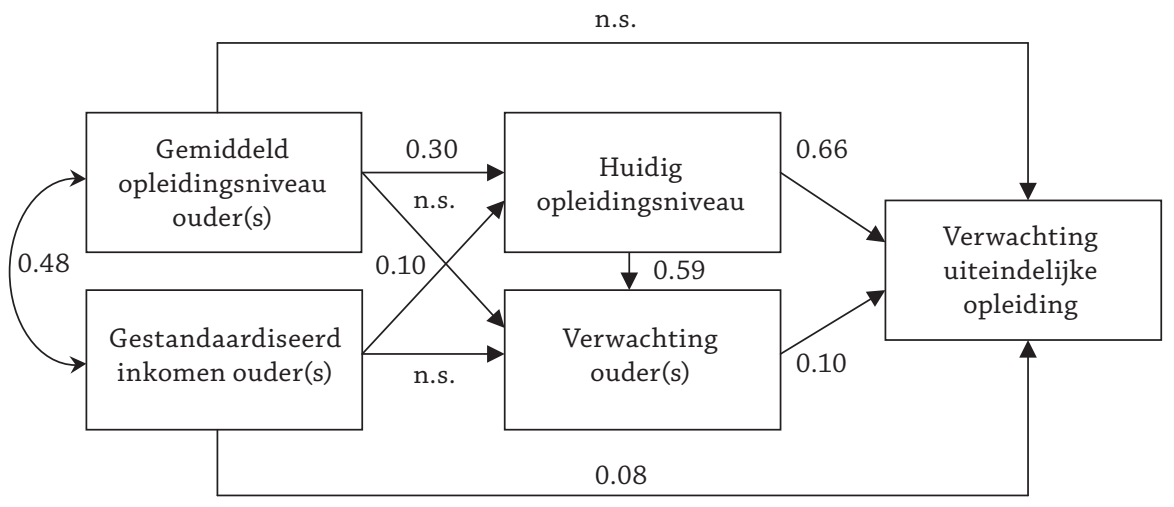

niveau als het inkomen van de ouder heeft effect op de toekomstverwachtingen van hun kind via het door het kind reeds bereikte niveau van voortgezet onderwijs. Kinderen van wie de ouders hoger zijn opgeleid en meer geld te besteden hebben, volgen vaker hogere niveaus van voortgezet onderwijs. Het effect van het opleidingsniveau van de ouders $(\beta=0,30)$ is drie keer zo sterk als dat van het inkomen $(\beta=0,10)$.

Het schoolniveau van de adolescent beïnvloedt vervolgens de toekomstverwachtingen over het uiteindelijk te bereiken opleidingsniveau. Dit gebeurt vooral direct, doordat kinderen op hogere niveaus van voortgezet onderwijs hogere opleidingsniveaus nastreven. Er is echter ook een kleiner indirect effect via de verwachtingen van de ouders: ouders met kinderen op hogere niveaus van voortgezet onderwijs verwachten ook een hoger eindniveau van opleiding $(\beta=0,59)$ en zij dragen deze ambitie (in beperkte mate) over op hun kinderen $(\beta=0,10)$.

Het effect van het inkomen van het ouderlijk huis wordt niet volledig gemedieerd. Waar het effect van opleidingsniveau van de ouders volledig verloopt via het schoolniveau van hun kind en hun verwachtingen over het te bereiken opleidingsniveau, is er een direct effect van het inkomen van de ouders op de verwachtingen van de adolescent $(\beta=0,08)$. Een hoger inkomen van de ouders leidt, ongeacht hun opleidingsniveau en dat van hun kind en ongeacht hun verwachtingen, tot hogere ambities bij hun kinderen.

De modellen voor economische en culturele beroepspreferenties zijn in figuur 3 en 4 weergegeven. Het opleidingsniveau en het inkomen van de ouders beïnvloeden de voorkeuren van hun kinderen voor beroepen vooral via het niveau van voortgezet onderwijs van hun kinderen. Kinderen van wie de ouders een hogere opleiding en een hoger inkomen hebben, volgen hoger niveaus van voortgezet onderwijs en hebben daardoor een sterkere voorkeur voor beroepen met een 
Figuur 3 Economische beroepspreferentie: effecten van sociale achtergrond, schoolniveau en verwachtingen van de ouders $(d f=1, X 2=0,45$, RMSEA $=0,0000, C F I=1$ )

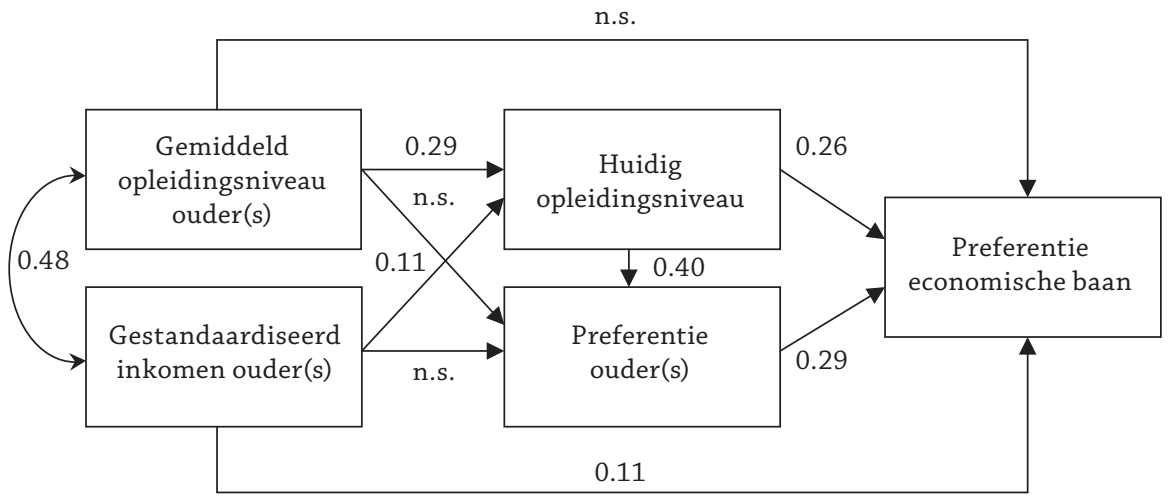

hogere status dan kinderen van wie de ouders lager zijn opgeleid en een lager inkomen hebben $(\beta=0,26$ en $\beta=0,31)$. Het niveau van voortgezet onderwijs leidt niet alleen direct tot hogere verwachtingen bij de kinderen, maar ook indirect. Ouders met kinderen op hogere schoolniveaus hebben (daardoor) hogere verwachtingen over de toekomstige beroepsstatus van hun kind $(\beta=0,40$ en $\beta=0,45)$ en dragen die verwachtingen ook over op hun kinderen $(\beta=0,29$ en $\beta=0,22)$.

Net als bij de verwachtingen over het te bereiken opleidingsniveau is er ook hier een direct effect van het inkomen van de ouders (en niet van hun opleidingsniveau). Los van het schoolniveau van de adolescent zelf en los van het opleidingsniveau en de verwachtingen van de ouders hebben kinderen uit hogere inkomensgroepen een sterkere voorkeur voor een beroep met een hoge status dan hun schoolgenoten $(\beta=0,11$ en $\beta=0,07)$. Dit kunnen zowel culturele beroepen zijn (muzikant, leraar) als meer economische beroepen (directeur). Opvallend is de overeenkomst tussen beide modellen: zowel de directe als de indirecte effecten van opleiding en inkomen van de ouders zijn voor culturele en economische beroepen nagenoeg even groot. In tegenstelling tot het geschatte model ter verklaring van het door de adolescent verwachte opleidingsniveau (figuur 2) zijn het effect van de ouderlijke verwachtingen en het effect van het huidige scholingsniveau op de verwachting van de adolescent in dezelfde orde van grootte. Dit duidt op een minder structurerend effect van het huidige scholingsniveau.

Figuur 5 geeft de effecten weer van de ouderlijke hulpbronnen op het belang dat men hecht aan traditionele gezinsvorming: trouwen en kinderen krijgen vóór iemands 30-jarige leeftijd. Zoals de totale effecten al lieten zien: het belang dat men hieraan hecht varieert nauwelijks met sociale achtergrond. Het schoolniveau, dat de verwachtingen over opleiding en beroep sterk structureerde, heeft geen effect op het belang dat gehecht wordt aan traditionele gezinsvorming. Er doen zich hier geen verschillen voor tussen leerlingen van lagere en hogere school- 
Figuur $4 \quad$ Culturele beroepspreferentie: effecten van sociale achtergrond, schoolniveau en verwachtingen van de ouders $(d f=1, X 2=0,27$, RMSEA $=0,0000$, CFI $=1$ )

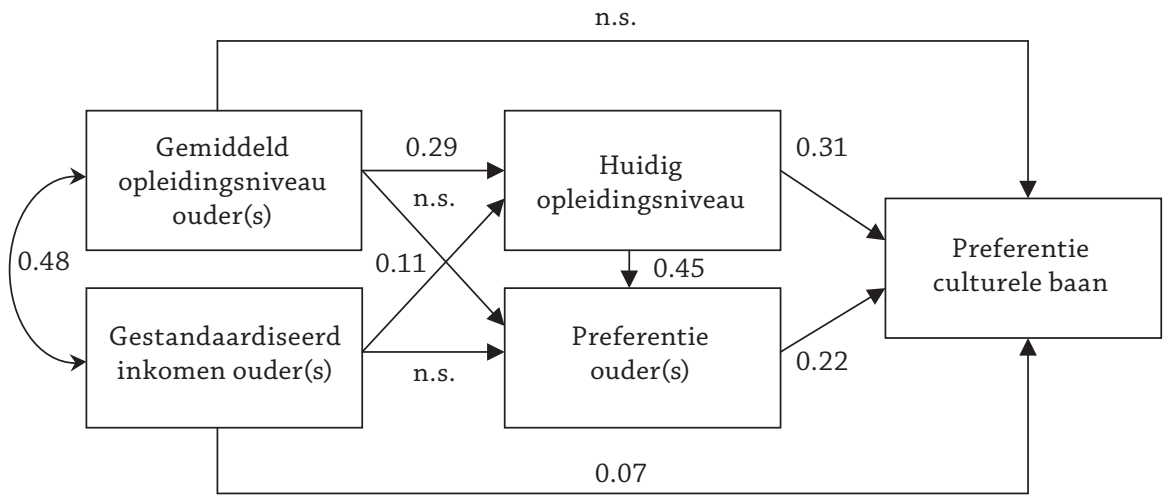

Figuur 5 Het belang van gezinsvorming: effecten van sociale achtergrond, schoolniveau en verwachtingen van de ouders $(d f=7, X 2=33$, RMSEA=0,062, $C F I=0,995$ )

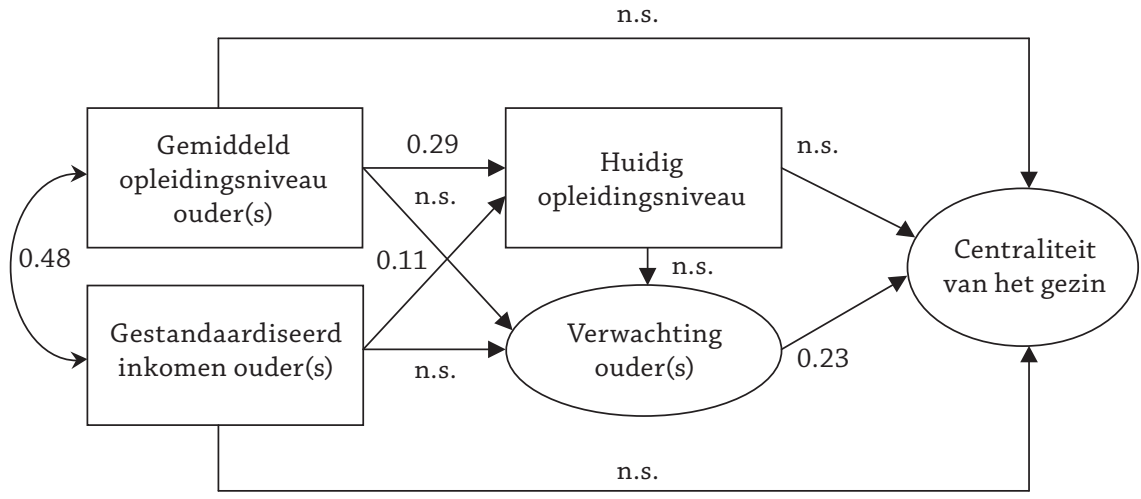

niveaus, niet rechtstreeks, en ook niet indirect via verwachtingen hierover bij hun ouders. De verwachtingen van de ouders omtrent gezinsvorming hebben, los van sociale achtergrond en schoolniveau, wel een effect $(\beta=0,23)$ : ouders die belang hechten aan traditionele patronen van relatie- en gezinsvorming geven deze in zekere mate door aan hun kinderen.

In figuur 6 zijn de effecten van sociaaleconomische herkomst geschat ter verklaring van de timing van gezinsvorming. Net als bij de verwachtingen over opleiding en beroep beïnvloeden het opleidingsniveau en het inkomen van de ouders de timing van levensloopgebeurtenissen via het schoolniveau van de adolescent. Leerlingen op hogere schoolniveaus, die in grotere mate afkomstig zijn uit gezin- 


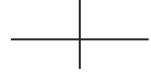

Figuur 6 De timing van gezinsvorming: effecten van sociale achtergrond, schoolniveau en verwachtingen van de ouders $(d f=37, X 2=129$, RMSEA $=0,050, C F I=0,987$ )

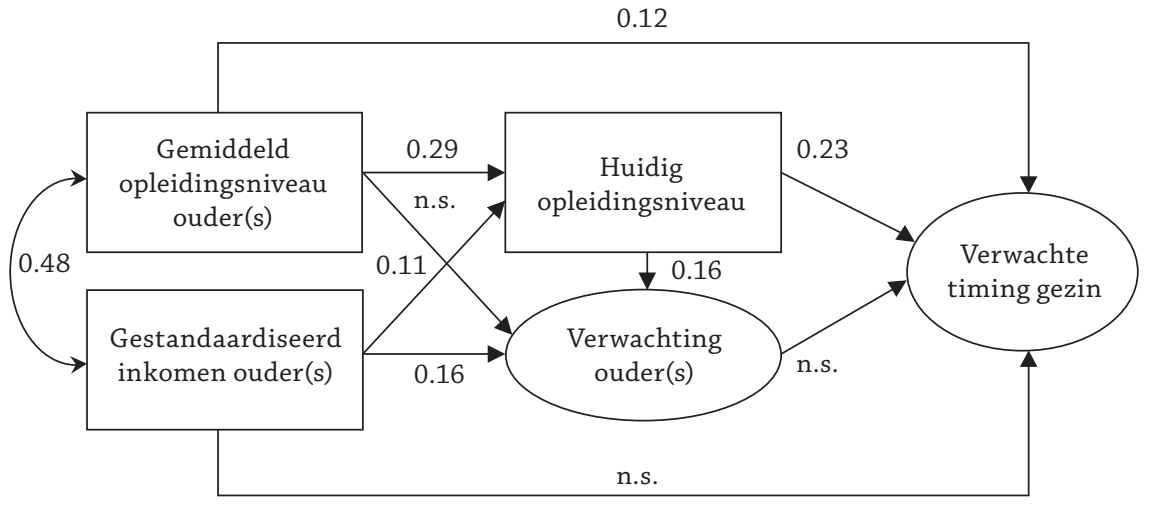

nen met een hogere sociaaleconomische positie, verwachten dat ze op latere leeftijd beginnen aan samenwonen, trouwen, kinderen krijgen en een huis kopen dan kinderen uit gezinnen met een lagere sociaaleconomische positie $(\beta=0,23)$. Hoewel ouders zich in hun verwachtingen over de timing van deze levensloopgebeurtenissen ook laten leiden door het niveau van voortgezet onderwijs van hun kind $(\beta=0,16)$, hebben deze verwachtingen geen invloed op de toekomstplannen van kind hierover.

Naast het indirecte effect van de sociale achtergrond van de ouders via het schoolniveau van hun kind heeft het opleidingsniveau van de ouders ook een direct effect op de gezinstiming van de adolescent $(\beta=0,12)$. Kinderen van hoger opgeleide ouders verwachten dat ze de stadia van gezinsvorming later doorlopen dan kinderen van lager opgeleide ouders, ongeacht hun eigen schoolniveau.

In tegenstelling tot de eerdere modellen is er geen direct inkomenseffect. De verwachtingen van de ouders omtrent timing worden beïnvloed door het huidige opleidingsniveau van hun kind $(\beta=0,16)$ en hun inkomen $(\beta=0,16)$. Het huidige opleidingsniveau van de adolescent $(\beta=0,23)$ heeft een significant effect op de verwachte timing van gezinsvorming door de adolescent.

\section{Conclusie en discussie}

Het doel van dit onderzoek is inzicht te krijgen in de invloed van de ouderlijke hulpbronnen op de toekomstverwachtingen van adolescenten. De verwachtingen van de adolescent hebben betrekking op beslissingen die in de late adolescentie en vroege volwassenheid plaats zullen vinden op het terrein van opleiding, beroep en relatie- en gezinsvorming. Omdat de adolescenten niet helemaal aan het begin staan van hun levensloop, is rekening gehouden met het reeds door de adolescent bereikte niveau van voortgezet onderwijs. Het niveau van voortgezet onderwijs 
kan beschouwd worden als een indicator voor de eigen capaciteiten van de adolescent en reflecteert ook deels de reeds verzilverde ouderlijke hulpbronnen. De verwachtingen van de ouders over de levensloop van hun kinderen zijn een indicatie voor de socialisatie van de ouders.

Hoe sterk zijn de effecten van ouderlijke hulpbronnen?

In de inleiding is een drietal vragen gesteld. De eerste deelvraag was: Wat binnen het ouderlijk huis beïnvloedt de toekomstplannen van de adolescent? Om deze vraag te beantwoorden zijn de ouderlijke hulpbronnen opgedeeld in economische en culturele hulpbronnen. Uit de gepresenteerde resultaten blijkt - enkele uitzonderingen daargelaten - dat zowel de culturele als de economische hulpbronnen die beschikbaar zijn in het ouderlijk huis de toekomstverwachtingen van adolescenten beïnvloeden. Naarmate de ouders over meer culturele hulpbronnen beschikken, verwachten de adolescenten een hoger opleidingsniveau en een beroep met een hogere culturele status te bereiken. Ook hechten adolescenten van wie de ouders veel culturele hulpbronnen hebben minder belang aan traditionele gezinsvorming en verwachten zij diverse transities op het terrein van relatie- en gezinsvorming later mee te maken dan adolescenten van wie de ouders weinig culturele hulpbronnen hebben. Daarnaast zijn ook de economische hulpbronnen die ouders beschikbaar hebben van belang: naarmate hun inkomen toeneemt, verwacht de adolescent een hoger opleidingsniveau en economische en culturele beroepsstatus te bereiken, en gezinsvorming uit te stellen.

De genoemde resultaten leiden tot drie interessante conclusies. Allereerst blijkt dat de toekomstverwachtingen die adolescenten koesteren samenhangen met de ouderlijke hulpbronnen, wat suggereert dat iemands sociale achtergrond nog steeds een invloed uitoefent op de ambities die men ontwikkelt met betrekking tot de eerste schreden op weg naar de volwassenheid. Hoewel de genoemde effecten niet spectaculair groot zijn, zijn ze wel consistent. Daarnaast is het vooral frappant om te zien dat het niet alleen om de culturele hulpbronnen van het ouderlijk huis gaat, maar ook om het inkomen dat ouders hebben. Hun adolescente kinderen verwachten mogelijk dat hun ouders die financiële hulpbronnen mede zullen inzetten om hun eerste schreden naar de volwassenheid makkelijker te laten verlopen. Deze resultaten sporen niet met de veronderstelling dat in Nederland inkomenseffecten steeds minder van belang zijn doordat de overheid het onderwijs voor een belangrijk deel financiert (De Graaf 1986). Mogelijk is het inkomenseffect ook te verklaren door de sociale context waarin de adolescent zich bevindt. In een sociale context met een inkomen hoger dan gemiddeld is de vraag bijvoorbeeld niet of je gaat studeren, maar wat je gaat studeren. De afruil tussen studeren (investeren) of werken (inkomsten genieten) is veel minder prangend vanwege de financiële ondersteuning van de ouders. Ten slotte blijkt de invloed van ouderlijke hulpbronnen op het belang dat adolescenten aan traditionele gezinsvorming hechten het geringst, wat suggereert dat op dit vlak andere kenmerken van het ouderlijk huis, bijvoorbeeld de mate van godsdienstigheid, een grotere rol zouden kunnen spelen. Dergelijke kenmerken zijn in dit onderzoek echter buiten beschouwing gelaten. 
Hoe beïnvloeden ouderlijke hulpbronnen de toekomstplannen?

Hoe worden toekomstplannen van adolescenten beïnvloed? was de tweede deelvraag. Daarbij besteedden we aandacht aan de rol van het door de adolescent bereikte opleidingsniveau enerzijds en de verwachtingen en wensen van de ouders anderzijds. Uit de resultaten blijkt dat vooral het door de adolescent reeds bereikte opleidingsniveau van cruciaal belang is. De verwachtingen van de adolescenten en van de ouders worden beide sterk beïnvloed door het niveau van voortgezet onderwijs van het kind, wat suggereert dat het laatste sterk structurerend is voor de toekomstverwachtingen. Verwachtingen en wensen van ouders spelen ook wel een rol, maar meestal toch in geringere mate dan het door de adolescent reeds bereikte opleidingsniveau. Dit beklemtoont dat sociale ongelijkheid in toekomstverwachtingen nog steeds in sterke mate wordt gereproduceerd door het onderwijsbestel, zoals reeds door Bourdieu gesuggereerd.

De resultaten laten overigens ook zien dat het relatieve belang van het schoolniveau van de adolescent en van de verwachtingen van ouders in de beïnvloeding van de toekomstverwachtingen van adolescenten varieert al naar gelang het type toekomstverwachting dat wordt bestudeerd. Zo is het opvallend dat het effect van het gezin (de verwachtingen van de ouders) op de beroepsverwachtingen van hun kind ongeveer even sterk is als het effect van de school (het huidige onderwijsniveau), terwijl het effect van de school op de verwachtingen ten aanzien van het te bereiken opleidingsniveau veel sterker is. Het huidige onderwijsniveau is dus minder structurerend bij de verwachte beroepspreferentie dan bij het verwachte uiteindelijke opleidingsniveau. De socialisatie door het ouderlijk huis speelt een net zo belangrijke rol. Wellicht komt dat doordat de beroepskeuze verder in de toekomst ligt dan de keuze voor de vervolgopleiding.

Verder laten de resultaten zien dat de invloed van ouderlijke culturele en economische hulpbronnen in sterke mate wordt gemedieerd door het bereikte opleidingsniveau van de adolescent en door de verwachtingen van de ouders. $\mathrm{Na}$ mediatie blijven er slechts enkele kleine directe effecten van inkomen en opleiding statistisch significant.

Zo is er bijvoorbeeld een direct effect van het opleidingsniveau van de ouders op de verwachting van hun kind omtrent de timing van gezinsvorming. Hoger opgeleide ouders waarderen doorstuderen, reizen en 'het vrijgezellenbestaan' waarschijnlijk meer en dragen dit over op hun kinderen. Daarnaast zijn er in de drie modellen aangaande opleiding en beroep, niet gemedieerde, directe effecten van het inkomen op de verwachtingen van de adolescent. Dit suggereert dat ouders met veel financiële hulpbronnen niet alleen hogere verwachtingen hebben omtrent de toekomstige keuzes van hun kind op het vlak van beroep en opleiding, maar dat de adolescent zelf ook verwacht dat financiële ondersteuning door de ouders hun carrière verder kan brengen. Daarnaast speelt mogelijk een rol dat adolescenten wier ouders een hoog inkomen hebben, gewend zijn aan een bepaalde levensstijl en sterk de wens koesteren om deze levensstijl te continueren (Easterlin 1995). 
Beïnvloeden hulpbronnen toekomstplannen in beide levensdomeinen?

De laatste deelvraag die gesteld is in de inleiding, is: Verschilt de invloed van de sociaaleconomische herkomst tussen verwachtingen in de sfeer van opleiding en beroep en de verwachtingen omtrent gezinsvorming en gezinstiming? De ouderlijke hulpbronnen blijken op alle toekomstverwachtingen effect te hebben. De invloed van de ouderlijke hulpbronnen op het verwachte uiteindelijke opleidingsniveau en de verwachte timing van gezinsvorming wordt sterk gestructureerd door het huidige scholingsniveau van de adolescent. De verwachtingen van de ouders en het huidige opleidingsniveau van de adolescent beïnvloeden ongeveer in dezelfde mate de verwachte beroepskeuze. De verwachte uiteindelijke opleiding en beroepskeuze en gezinstiming hangen positief samen met de ouderlijke hulpbronnen.

Als ouders meer hulpbronnen hebben, verwachten adolescenten serieuze stappen op het pad van gezinsvorming nog wat uit te stellen. Het beeld is echter anders wanneer gekeken wordt naar de waarde die adolescenten hechten aan traditionele 'markers' van gezinsvorming, zoals huwelijk en ouderschap. Het belang dat de adolescent hecht aan gezinsvorming blijkt het minst sterk beïnvloed te worden door de ouderlijke hulpbronnen. Waarschijnlijk spelen hier niet zozeer ouderlijke hulpbronnen een rol, maar eerder de godsdienstige oriëntatie in het ouderlijk huis.

\section{Slotopmerkingen}

Een opvallende uitkomst van deze studie is verder dat - in vergelijking tot hun adolescente kinderen - ouders verwachten dat veel transities in het gezinsleven later plaats zullen vinden. Dit is opmerkelijk, omdat de ouders zelf veel van deze transities op relatief jonge leeftijd meegemaakt zullen hebben (Liefbroer en Dykstra 2000). Mogelijk speelt hier een rol dat adolescenten wat al te optimistisch zijn over hoe snel zij er in de toekomst in zullen slagen gewenste levenslooptransities te realiseren, terwijl hun ouders op dit punt een wat realistischer perspectief weten te hanteren (Weinstein 1980).

Ten slotte willen wij nog wijzen op enkele methodologische beperkingen en uitdagingen. In de eerste plaats is in deze studie uitgegaan van een uni-directionele beïnvloeding van de verwachtingen van kinderen door hun ouders. In werkelijkheid is er eerder sprake van een wisselwerking tussen ouders en kinderen. Wel blijkt uit eerder onderzoek dat het effect van ouders op kinderen sterker is dan andersom (Roest 2009). Panelonderzoek waarbij zowel ouders als kinderen in de loop van de tijd gevolgd worden, zou het mogelijk maken deze wederzijdse beïnvloeding van verwachtingen nader te bestuderen.

In de tweede plaats hebben wij geen aandacht besteed aan het realiteitsgehalte van de verwachtingen van de adolescenten. Dit was ook niet mogelijk, omdat deze studie is gebaseerd op een cross-sectionele dataset. Interessant zou zijn om met behulp van paneldata in de loop van de tijd te kijken tot welke leeftijd en in welke mate de sociaaleconomische herkomst effect houdt op de toekomstverwachtingen van de adolescent. Daarnaast zou met een longitudinaal onderzoek bekeken kunnen worden in welke mate de verwachtingen gerealiseerd zijn en welke variabelen daarbij van belang zijn. 


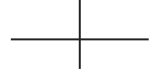

\section{Literatuur}

Aldous, J. en R. Hill (1965) Social cohesion, lineage type, and intergenerational transmission. Social Forces, 471-482.

Anderson, M. (2005) Timespans and Plans Among Young Adults. Sociology 39 (1), 139-155.

Arnett, J.J. (2000) Emerging adulthood: A theory of development from the late teens through the twenties. American Psychologist 55 (5), 469-480.

Axinn, W. en A. Thornton (1992) The influence of parental resources on the timing of the transition to marriage. Social Science Research 261-285.

Axinn, W. en A. Thornton (1993) Mothers, children, and cohabitation: The intergenerational effects of attitudes and behavior. American Sociological Review, 233-246.

Beal, S.J. en L.J. Crockett (2010) Adolescents' occupational and educational aspirations and expectations: Links to high school activities and adult educational attainment. Developmental Psychology 46 (1), 258-265.

Beck, U. en E. Beck-Gernsheim (2002) Individualization: Institutionalized individualism and its social and political consequences (vol. 13). Sage Publications Ltd.

Becker, G. (1974) A theory of social interactions. Journal of Political Economy 82 (6), 1063-1093.

Billari, F. en A. Liefbroer (2007) Should I stay or should I go? The impact of age norms on leaving home. Demography, 181-198.

Blossfeld, H.P. (2005) Globalization, uncertainty and youth in society (vol. 15). Psychology Press.

Blossfeld, H. en J. Huinink (1991) Human capital investments or norms of role transition? How women's schooling and career affect the process of family formation. American Journal of Sociology, 143-168.

Boehnke, K., A. Hadjar en D. Baier (2007) Parent-Child Value Similarity: The Role of Zeitgeist. Journal of Marriage and Family 69 (3), 778-792.

Bourdieu, P. (1986) The forms of capital. Readings in economic sociology, 280-291.

Bourdieu, P. en J.C. Passeron (1977) La reproduction: éléments pour une théorie du système d'enseignement. Parijs: Minuit.

Bowden, M.P. en J. Doughney (2011) The importance of cultural and economic influences behind the decision to attend higher education. Journal of Socio-Economics 41 (1), 95-103.

Brannen, J. en A. Nilsen, A. (2002) Young people's time perspectives: From youth to adulthood. Sociology 36 (3), 513-537.

Breen, R. en J.H. Goldthorpe (1997) Explaining educational differentials. Rationality and Society 9 (3), 275-305.

Brückner, H. en K.U. Mayer (2005) De-standardization of the life course: What it might mean? And if it means anything, whether it actually took place. The Structure of the Life Course: Standardized? Individualized? Differentiated 9, 27-54.

Clarkberg, M. en P. Moen (2001) Understanding the Time-Squeeze Married Couples' Preferred and Actual Work-Hour Strategies. American Behavioral Scientist, 1115-1136.

Coleman, J.S. (1988) Social capital in the creation of human capital. American Journal of Sociology, 95-120.

Conger, R.D., K.J. Conger en M.J. Martin (2010) Socioeconomic status, family processes, and individual development. Journal of Marriage and Family 72 (3), 685-704.

Crockett, L.J. en S.J. Beal (2012) The Life Course in the Making: Gender and the Development of Adolescents' Expected Timing of Adult Role Transitions. Developmental Psychology. 
Davies, M. en D. Kandel (1981) Parental and peer influences on adolescents' educational plans: Some further evidence. American Journal of Sociology, 363-387.

Dronkers, J. en P.M. de Graaf (1995) Ouders en het onderwijs van hun kinderen. Verschuivende ongelijkheid in Nederland: Sociale gelaagdheid en mobiliteit, 46. Van Gorcum, hoofdstuk 4.

Duncan, O.D. en R.W. Hodge (1963) Education and Occupational Mobility a Regression Analysis. American Journal of Sociology, 629-644.

Easterlin, R.A. (1995) Will raising the incomes of all increase the happiness of all? Journal of Economic Behavior \& Organization 27 (1), 35-47.

Furlong, A. en F. Cartmel (1997) Young people and social change: Individualization and risk in late modernity. Open University Press.

Ganzeboom, H., P.M. de Graaf en M. Kalmijn (1987) De culturele en economische dimensie van beroepsstatus. Mens en Maatschappij 62 (2), 153-175.

Ganzeboom, H.B.G., P.M. de Graaf en D.J. Treiman (1992) A standard international socioeconomic index of occupational status. Social Science Research 21 (1), 1-56.

Ganzeboom, H., I. Nagel en A.C. Liefbroer (2005-2006) [p.i.] Youth and Culture. A Multiactor Panel Study; Cultural participation and future plans (machine readable datafiles). Amsterdam: Vrije Universiteit (producer), to be archived.

Giddens, A. (1991) Modernity and self-identity: Self and society in the late modern age. Stanford University Press.

Goyette, K.A. (2008) College for some to college for all: Social background, occupational expectations, and educational expectations over time. Social Science Research 37 (2), 461-484.

Graaf, P.M. de (1986) The impact of financial and cultural resources on educational attainment in the Netherlands. Sociology of Education, 237-246.

Graaf, P.M. en H.B.G. Ganzeboom (1993) Family background and educational attainment in the Netherlands for the 1891-1960 birth cohorts. Persistent inequality: Changing educational attainment in thirteen countries, 75-99.

Harvey, D.G. en G.T. Slatin (1975) The Relationship between Child's SES and Teacher Expectations: A Test of the Middle-Class Bias Hypothesis. Social Forces 54, 140-159.

Hogan, D. en N. Astone (1986) The transition to adulthood. Annual Review of Sociology, 109-130.

Iyengar, S.S. en M.R. Lepper (2000) When choice is demotivating: Can one desire too much of a good thing? Journal of Personality and Social Psychology 79 (6), 995-1006.

Jacob, B.A. en T. Wilder (2010) Educational Expectations and Attainment. <http:// www.nber.org/papers/w15683>.

Jong-Gierveld, J.D.E.J. de, A.C. Liefbroer en E. Beekink (1991) The effect of parental resources on patterns of leaving home among young adults in the Netherlands. European Sociological Review 7 (1), 55-71.

Kalmijn, M. (1998) Intermarriage and homogamy: Causes, patterns, trends. Annual Review of Sociology, 395-421.

Kim, D.H. en B.L. Schneider (2006) Social capital in action: Alignment of parental support in adolescents' transition to postsecondary education. Social Forces 84 (2), 1181-1206.

Kohn, M.L. (1963) Social class and parent-child relationships: An interpretation. American Journal of Sociology, 471-480.

Kraaykamp, G.L.M. (2009) Culturele socialisatie: een zegen en een vloek: verbreding en verdieping in het sociologisch onderzoek naar langetermijneffecten van culturele opvoeding (inauguratierede). 
